\title{
Seasonal Distributions and Movements of Longnose Gar (Lepisosteus osseus) within the York River System, Virginia
}

\author{
Patrick E. McGrath \\ Eric J. Hilton \\ Virginia Institute of Marine Science \\ John A. Musick \\ Virginia Institute of Marine Science
}

Follow this and additional works at: https://scholarworks.wm.edu/vimsarticles

Part of the Aquaculture and Fisheries Commons, and the Marine Biology Commons

\begin{abstract}
Recommended Citation
McGrath, Patrick E.; Hilton, Eric J.; and Musick, John A., Seasonal Distributions and Movements of Longnose Gar (Lepisosteus osseus) within the York River System, Virginia (2012). Southeastern Naturalist, 11(3), 375-386.

doi: $10.1656 / 058.011 .0302$
\end{abstract}

This Article is brought to you for free and open access by the Virginia Institute of Marine Science at W\&M ScholarWorks. It has been accepted for inclusion in VIMS Articles by an authorized administrator of W\&M ScholarWorks. For more information, please contact scholarworks@wm.edu. 


\title{
Seasonal Distributions and Movements of Longnose Gar (Lepisosteus osseus) within the York River System, Virginia
}

\author{
Patrick E. McGrath ${ }^{1, *}$, Eric J. Hilton ${ }^{2}$, and John A. Musick ${ }^{2}$
}

\begin{abstract}
The seasonal movements of Lepisosteus osseus (Longnose Gar) are largely unknown. The goal of this project was to characterize spawning movements and seasonal distributions by using acoustic tagging methods and examining historical catch records from a trawl survey. This is the first time that movements have been studied for an estuarine population of Longnose Gar. Two individuals moved greater minimum distances (69 and $74 \mathrm{~km}$ ) than found in the only other report on movement in this species. Spawningground residency time, collected from two tagged Longnose Gar, was approximately one month, and tidal periodicity was observed for one of the two fish. Data from a fisheries independent trawl survey were used to examine seasonal catch distributions in Longnose Gar and represents the first report of winter distributions for this species. Winter locations occurred both alongshore and mid-channel, and the distributions were similar to those in the summer and fall.
\end{abstract}

\section{Introduction}

Many fishes undergo spawning movements to find either suitable mates or habitat (Leggett 1977). The extent of the movements can provide knowledge about the energy needed before or during the migration. Information on the timing, duration, or preferred habitat of the migration allows for a better understanding of a species during a critical stage within the life cycle. This period, when many of the adults can be found in large aggregations and the next generation is being created, is often the subject of management practices.

The spawning movements and seasonal distributions for most populations of lepisosteids are largely unknown or unreported. This lack of data is especially true for populations of Lepisosteus osseus L. (Longnose Gar) inhabiting tidal estuaries. The available literature primarily concerns spawning movements of entirely freshwater populations of Longnose Gar characterized through conventional tagging methods (Johnson and Noltie 1996). Johnson and Noltie (1996) found the spawning migration to be broad and extensive, positively correlated with stream flow and water level, and negatively correlated with temperature. Longnose Gar displayed a small degree (12.5\%) of yearly site fidelity to the spawning ground, and individuals were recaptured up to $48 \mathrm{~km}$ away after the spawning season (Johnson and Noltie 1996).

Only two studies utilizing acoustics to map distributions of gars have been published. Lepisosteus oculatus Winchell (Spotted Gar) were tagged with a radio transmitter in the Lower Atchafalaya River Basin, LA and monitored throughout

${ }^{1}$ Chesapeake Bay Governor's School, PO Box 1410, Tappahannock, VA 22560. ${ }^{2}$ Virginia Institute of Marine Science, College of William and Mary, PO Box 1346, Gloucester Point, VA 23062. "Corresponding author - pmcgrath@cbgs.k12.va.us. 
the year (Snedden et al. 1999). Areas of relocation were found to be largest during the spring and smallest during the fall-winter. Movements increased as the water temperature and river stage rose in the spring and included the inundated floodplain, which provided spawning habitat. Atractosteus spatula Lacepède (A1ligator Gar) has also been tracked in the Mobile-Tensaw Delta, AL and had linear movements between 2.73 and $12.25 \mathrm{~km}$ (Sakaris et al. 2003).

Spawning appears to be the driving force for the longest movements of lepisosteids (Johnson and Noltie 1996, Sakaris et al. 2003, Snedden et al. 1999). The primary goal of this project was to elucidate the spawning movements of Longnose Gar in a tidally influenced river system (the York River System [YRS]) by using acoustic tagging methods. It was hypothesized that Longnose Gar residing in tidal habitats would move further than individuals from entirely freshwater systems due to the necessity of moving from mesohaline water to freshwater. Longnose Gar has been documented as a resident in bodies of water with salinity values reaching 31 ppt (Jean 1946, Schwartz 2003); however, it still requires a freshwater region for egg maturation and larval growth. The freshwater region within this study is tidally influenced, which led to a second hypothesis that tidal stage would influence the timing and duration upon the spawning grounds. It was believed that Longnose Gar would move over the spawning grounds during high tide when water levels were the deepest and more possible spawning locations submerged.

A second goal of this study was to characterize the seasonal distribution of Longnose Gar by examining catch data from a multi-year trawl survey. It was expected that Longnose Gar would be located upstream during the spring spawning season, and then spread throughout the YRS during the summer and fall to minimize intraspecific competition for prey items. Winter distributions have not been described for Longnose Gar, but based on Snedden et al.'s (1999) research on Spotted Gar, it was believed their movements would be limited, and therefore the distributions would be similar to the summer and fall.

\section{Field Site Description}

The Mattaponi and Pamunkey rivers converge at West Point, VA to form the York River (Fig. 1). These three rivers form the YRS, which is the fifth largest tributary of Chesapeake Bay. The YRS comprises a main channel that varies between 6 and $14 \mathrm{~m}$ wide and up to $20 \mathrm{~m}$ deep, and broad, shallow shoals less than $2 \mathrm{~m}$ in depth (Nichols et al. 1991, Reay and Morre 2009). The channel bed is dominated by a mud bottom, with occasional sand and shell, whereas the shoals are typically sandier (Friedrichs 2009). The mouth of the YRS is polyhaline with average tides of $0.7 \mathrm{~m}$, whereas the upper reaches of the Mattaponi and Pamunkey are freshwater with a tidal range of $1 \mathrm{~m}$ (Reay and Moore 2009, Sisson et al. 1997). Water temperatures vary considerably with season, ranging from 0 to 31 ${ }^{\circ} \mathrm{C}$ (Murdy et al. 1997). Nine tidal wetland community types are found within the YRS, ranging from Saltmarsh Cordgrass to Tidal Freshwater Mixed (Perry and Atkinson 2009). Submerged aquatic vegetation is dominated by Zostera marina 
L. (Eelgrass) and Ruppia maritime L. (Widgeon Grass) at the mouth of the YRS and Hydrilla verticulatta (L.f.) Royle (Hydrilla) in the tidal freshwater regions (Orth et al. 2005, Moore 2009, Shields 2008).

Sandy Point is located $75 \mathrm{Km}$ from the mouth of the York River (RKM 75) in the tidal freshwater region of the Mattaponi River and is characterized by an approximately 10 -m-wide sand/mud shelf dominated by Hydrilla. Freshwater

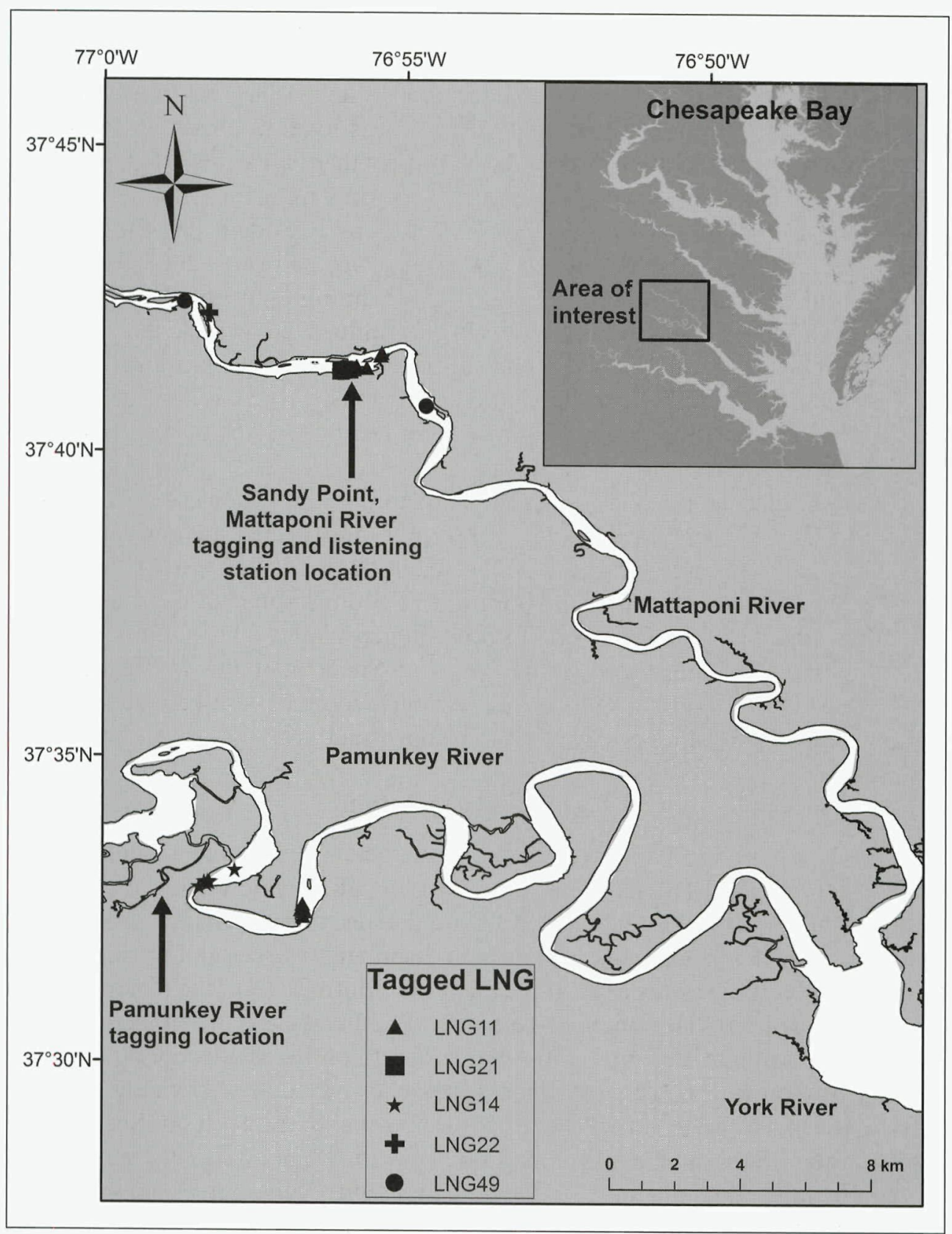

Figure 1. Locations of the five successfully tracked Longnose Gar (LNG), tagging areas, and listening station. 
marshes, with a mix of Nuphar luteum (L.) J.E. Smith (Yellow Pond Lily), Peltandra virginica (L.) Schott (Arrow Arum), and Pontederia cordata L. (Pickerel Weed), occur on both the upriver and downriver sides of Sandy Point (P.E. McGrath, pers. observ.). The tagging location on the Pamunkey River was on a 7-m-wide creek that drains into the Pamunkey River near the Cumberland Nature Preserve. The vegetation was very similar to Sandy Point, with the tagging location dominated by Hydrilla and a mix of Yellow Pond Lilies, Arrow Arum, and Pickerel Weed occurring both upstream and downstream.

\section{Methods}

Historical data collected by the Virginia Institute of Marine Science (VIMS) Juvenile Fish and Blue Crab Trawl Survey from 1979 to 2008 were examined for temporal trends in abundance and location of Longnose Gar within the Pamunkey and York Rivers. Unfortunately, this survey does not include stations on the Mattaponi River. The trawl survey collects fishes from fixed and random stations monthly using a 30-foot otter trawl with a tickler chain (Tuckey and Fabrizio 2010). Trawling is not an ideal method for collecting Longnose Gar, and the catch data were not indicative of their overall abundance. It would be improper to utilize statistical tests and associate significance values with this data. However, a catch per unit effort (CPUE; calculated as number of Longnose Gar caught per tow) was calculated for each index station and for each season. Seasonal CPUE's were calculated by averaging the CPUE data from each index station. This data was used as a non-statistical comparison of seasonal relative abundances and distributions between each fixed station. A CPUE could not be calculated for the general collection locations because these sites were selected at random each month in only the York River. However, this data was still utilized as a gross examination of the seasonal location of Longnose Gar. Relative abundance at the fixed stations and general collection locations of Longnose Gar were compared among Winter (December, January, and February), Spring (March, April, and May), Summer (June, July, and August), and Fall (September, October, and November).

Longnose Gar $(n=17)$ were tagged with thirteen radio (MCFT-3FM and SR-TPH-25) and four dual radio/ultrasonic (CS-11-25) transmitters (Lotek Wireless Inc., Newmarket, ON, Canada) to further evaluate seasonal and spawning movements and habitat preferences (Table 1). The radio transmitters are limited to freshwater, while the dual radio/ultrasonic transmitters can be heard in both freshwater and marine habitats. All individuals were tagged during the spawning season and on the spawning grounds. In the Pamunkey River, Longnose Gar were tagged in a creek off the Cumberland Thoroughfare near the Cumberland Nature Preserve. In the Mattaponi River, Longnose Gar were tagged at Sandy Point (Fig. 1). A greater number of Longnose Gar was tagged in the Mattaponi River due to a 24-hour tracking system stationed at Sandy Point. Longnose Gar were caught by tended gillnets and tail-roped at the river's edge or alongside the boat until surgery could be performed. Healthy 
Longnose Gar were then measured and fitted with acoustic tags. Tagging methods were similar to those of Sneddon et al. (1999). In brief, tagging consisted of drilling two small holes through the scale jacket at the base of the dorsal fin, threading a thin metal wire attached to the tag through holes in the fish and the tag, and then knotting the wire to ensure the tag remained in place. The wound was then rinsed with iodine, and the Longnose Gar were held for at least 15 minutes to allow for recovery. Once fish were swimming normally, they were released and tracked periodically over the life of the tag.

A Lotek yagi antenna (used when salinity was less than $1 \mathrm{ppt}$ ), hydrophone (used when salinity was greater than $1 \mathrm{ppt}$ ), and receiver were used during the active tracking portion of this project. Active tracking consisted of searching for tagged fish during various fishery surveys. In 2007, active tracking occurred during a bimonthly gillnet survey and consisted of kayaking a half mile upstream and downstream from the original tagging locations. In 2008, active tracking occurred aboard a small vessel while completing a monthly gillnet survey. The survey was completed over the course of four days ( 8 hours/day) and consisted of travel from RKM 40 on the York River to RKM 107 on both the Mattaponi and Pamunkey Rivers. Active tracking also occurred opportunistically in the Pamunkey and Mattaponi Rivers while accompanying the VIMS Juvenile Striped Bass Seine Survey (12 trips/year; July-September, 2007 and 2008; RKM 33 to 55) and VIMS American Shad Pushnet Survey (24 trips, February-May, 2007; RKM 79 to 131). When a Longnose Gar was located, the following data were recorded: Longnose Gar number, position (eTrex GPS unit, Garmin, Olathe, KS), air temperature, water temperature, and salinity.

Table 1. Date, tag model, tagging location, size, time between initial tagging and last position recorded (duration), number of relocations (rel.), minimum distance traveled, and status of acoustically tagged Longnose Gar.

\begin{tabular}{|c|c|c|c|c|c|c|c|c|}
\hline ish \# & Date & $\begin{array}{l}\text { Tag model } \\
\text { (life span in days) }\end{array}$ & River & $\underset{(\mathrm{mm} \mathrm{TL})}{\text { Size I }}$ & $\begin{array}{l}\text { Duration } \\
\text { (days) }\end{array}$ & Rel. & $\begin{array}{l}\text { distance } \\
(\mathrm{km})\end{array}$ & Status \\
\hline 1 & $6 / 6 / 2007$ & 1CFT-3FM (472) & Mattaponi & 1110 & 383 & 14 & 69.0 & Alive \\
\hline 12 & $6 / 7 / 2007$ & MCFT-3FM (472) & Pamunkey & 880 & 356 & 9 & 3.7 & Dead \\
\hline 13 & $5 / 25 / 2007$ & MCFT-3FM (472) & Pamunkey & 1002 & 1 & 1 & 0 & Missir \\
\hline 4 & $5 / 16 / 2007$ & MCFT-3FM (472) & Mattaponi & 1018 & 396 & 11 & 74.0 & Alive \\
\hline 5 & $5 / 25 / 2007$ & MCFT-3FM (472) & Pamunkey & 860 & 345 & 5 & 3.5 & Dead \\
\hline 6 & $6 / 6 / 2007$ & MCFT-3FM (472) & Mattaponi & 900 & 1 & 2 & 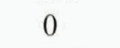 & Missir \\
\hline 7 & $5 / 16 / 2007$ & MCFT-3FM (472) & Matta! & 857 & 335 & 3 & 1.2 & Dead \\
\hline 8 & $5 / 10 / 20$ & MCFT-3FM (472) & Matt & 801 & 74 & 7 & 7. & Dead \\
\hline 19 & $5 / 10 / 2008$ & MCFT-3FM (472) & Matt & 736 & 12 & 2 & 2.0 & Missing \\
\hline 20 & $5 / 16 / 2008$ & SR-TP11-25 (497) & Matt & 885 & 1 & 1 & 0 & Missing \\
\hline 21 & $5 / 16 / 2008$ & SR-TP11-25 (497) & Matt & 885 & 29 & 19 & 0. & Alive \\
\hline 22 & $5 / 16 / 2008$ & SR-TP11-25 (497) & Matt & 836 & 35 & 167 & 4. & Alive \\
\hline 23 & $5 / 22 / 2008$ & SR-TP11-25 (497) & Mat & 885 & 1 & 2 & 0.2 & Missing \\
\hline 46 & $6 / 5 / 2008$ & CS-11-25 (418) & $\mathrm{Ma}$ & 998 & 1 & 1 & 0 & issing \\
\hline 47 & $5 / 22 / 2008$ & CS- 1 & $\mathrm{Ma}$ & 971 & 26 & 2 & 0.6 & issing \\
\hline 48 & $5 / 22 / 2$ & & & 1085 & 1 & 1 & 0 & iissing \\
\hline 49 & $6 / 3 / 2008$ & CS-11-25 (418) & Mattaponi & 900 & 70 & 7 & 9.0 & Alive \\
\hline
\end{tabular}


A fixed listening station was placed at Sandy Point on the Mattaponi River from March 2008 to July 2009 (Fig. 1). This listening station was set up to detect fish at the spawning grounds 24 hours a day and recorded when tagged Longnose Gar arrived, the duration of their stay, and time of their departure from the spawning ground. The complete area of detection on the spawning grounds was unknown, although it covered at least from the shoreline to the edge of the channel (approximately $10 \mathrm{~m}$ ). The listening station was programmed to search for a signal every minute, although for the purposes of analyses we examined detections every fifteen minutes. This reduced the number of detections and made it easier to identify tidal movements and duration of stays within the detection zone. Tidal stages were broken into three parts: high tide, low tide, and intermediate tide. High tide was 90 minutes before and after slack high water, low tide was 90 minutes before and after slack low water, and intermediate tide was the time between high and low tide.

Fish were categorized as dead, missing, or alive. Dead fish were either inactive for more than six months or were individuals with signals that were coming from land. Missing fish were individuals located on fewer than three days. Alive fish were located and displayed movement on three or more days. Dead and missing fish were removed from the analyses. ArcGIS (ESRI, Redlands, CA) was used to measure minimum distance moved for each fish.

\section{Results}

Five fish were presumed to be alive and were located on three or more days. The other tagged fish were either declared missing $(n=8)$ or dead $(n=4)$. Acoustically tagged Longnose Gar were relocated between March and August in areas with water temperatures ranging from $11-31^{\circ} \mathrm{C}$ and salinity values between 0 and $1 \mathrm{ppt}$. Movements of Longnose Gar were not correlated to temperature except for the two fish located by the passive listening array. The average time between initial release and last detection was 182.6 days, and the range in days between initial release and last detection was 35-396 days. The average minimum distance traveled was 31.4 $\mathrm{km}$. Two individuals traveled much further, moving between the Mattaponi and Pamunkey rivers.

Longnose Gar \#11 (LNG11) was tagged in June 2007 at Sandy Point on the Mattaponi River, and was relocated in the Pamunkey River in March 2008 (Fig. 1). The minimum in-stream linear distance traveled from the initial tagging location was $69 \mathrm{~km}$. This fish remained in the same general location in the Pamunkey River for the next few months until the tag presumably failed at the end of June. LNG14 had similar movement patterns as LNG11. It was also tagged at Sandy Point in May 2007 and not relocated again until August 2007 in the Pamunkey River (Fig. 1). The minimum in-stream linear distance traveled from the initial tagging location was $74 \mathrm{~km}$. This individual was then relocated in the same general area of the Pamunkey (RKM 73-75) several times until the tag presumably failed in June 2008. 
LNG49 was relocated seven times over the course of 70 days (Fig. 1). This fish first was located upstream after one week of being at liberty and then moved downstream of the initial tagging location $(9 \mathrm{~km})$ and remained in this general location until it was no longer detected in August of 2008. This could have been a result of tag malfunction or movement into brackish water where signals became more difficult to locate.

Two individuals (LNG21 and LNG22) were the only tagged fish to be located by the fixed listening station. LNG21 was never located with active tracking equipment. This fish was first relocated by the listening station 20 days after being tagged, when it remained within the area of detection during low tide for one hour before moving away once the tide began to flood. LNG21 returned into the area of detection 10 days later and remained there for the three hours surrounding low tide. On two separate days, this fish was located in the area of detection 17 times during low tide, once between tides, and never at high tide. LNG22 was located $4.8 \mathrm{~km}$ upstream six days after tagging. This was the only instance when this fish was found during active tracking. LNG22 was located by the listening station nine days after tagging. This fish continuously swam in and out of detection range for 12 days, with the longest continuous detection lasting 25 hours. LNG22 was relocated by the passive listening station twice more during the next two weeks, both times lasting less than 15 minutes. The last detection occurred 35 days after the initial tagging event. LNG22 was located by the passive listening station 52, 46, and 67 times during high tide, low tide, and intermediate tide, respectively. Both fish left the area of detection when water temperature reached $29^{\circ} \mathrm{C}$.

Longnose Gar $(n=225)$ were caught by the trawl survey from RKM 38 to 64 (Fig. 2). Water temperatures ranged from $4-31{ }^{\circ} \mathrm{C}$ and salinity values ranged from $0-18$ ppt. Longnose Gar were primarily caught in the Pamunkey River, but catches also occurred in the York River during each season except for the spring. More than half of the individuals $(n=149)$ were caught from the fixed (index) stations (referred to as index fish). All index fish were caught at the upper three index stations (stations 130, 135, and 140) located in the Pamunkey River. For this reason, the seasonal CPUE was calculated as the average CPUE from stations 130,135 , and 140 .

Winter catches were the lowest of all seasons, with an average CPUE $=0.004$ and only occasional catches occurring throughout the Pamunkey and upper York rivers (Figs. 2a, 3). During the spring, all individuals were caught in the Pamunkey River, and most of the index fish (average CPUE $=0.03$ ) were caught at furthest upriver station (140; RKM 64; Figs. 2b, 3). Longnose Gar were caught more often in the summer (average CPUE $=0.06$ ) and fall (average CPUE $=$ 0.07). Summer and fall distributions were spread throughout the Pamunkey and upper York rivers (Fig. 2c, d). The index fish in the summer were more frequently caught at station 130 (RKM 48) and then decreased with each upriver index station, while index fish in the fall were evenly spread between the upper three stations (Figs. 2c, 2d, and 3). 


\section{Discussion}

\section{Seasonal movements and distributions}

A portion of the population of Longnose Gar in the York River System appears to undergo extensive movements during the spring spawning season. Evidence to support this was provided by the long distance movements of the two tagged fish, the trawl survey's seasonal catch distribution, and the lack of tagged fish remaining near the spawning site. Two individuals moved from the freshwater region of the Mattaponi River through brackish water and into the freshwater region of the Pamunkey River. The minimum distance travelled by both fish (69 and $74 \mathrm{~km}$ ) was greater than the only other report on long-distance movements of Longnose
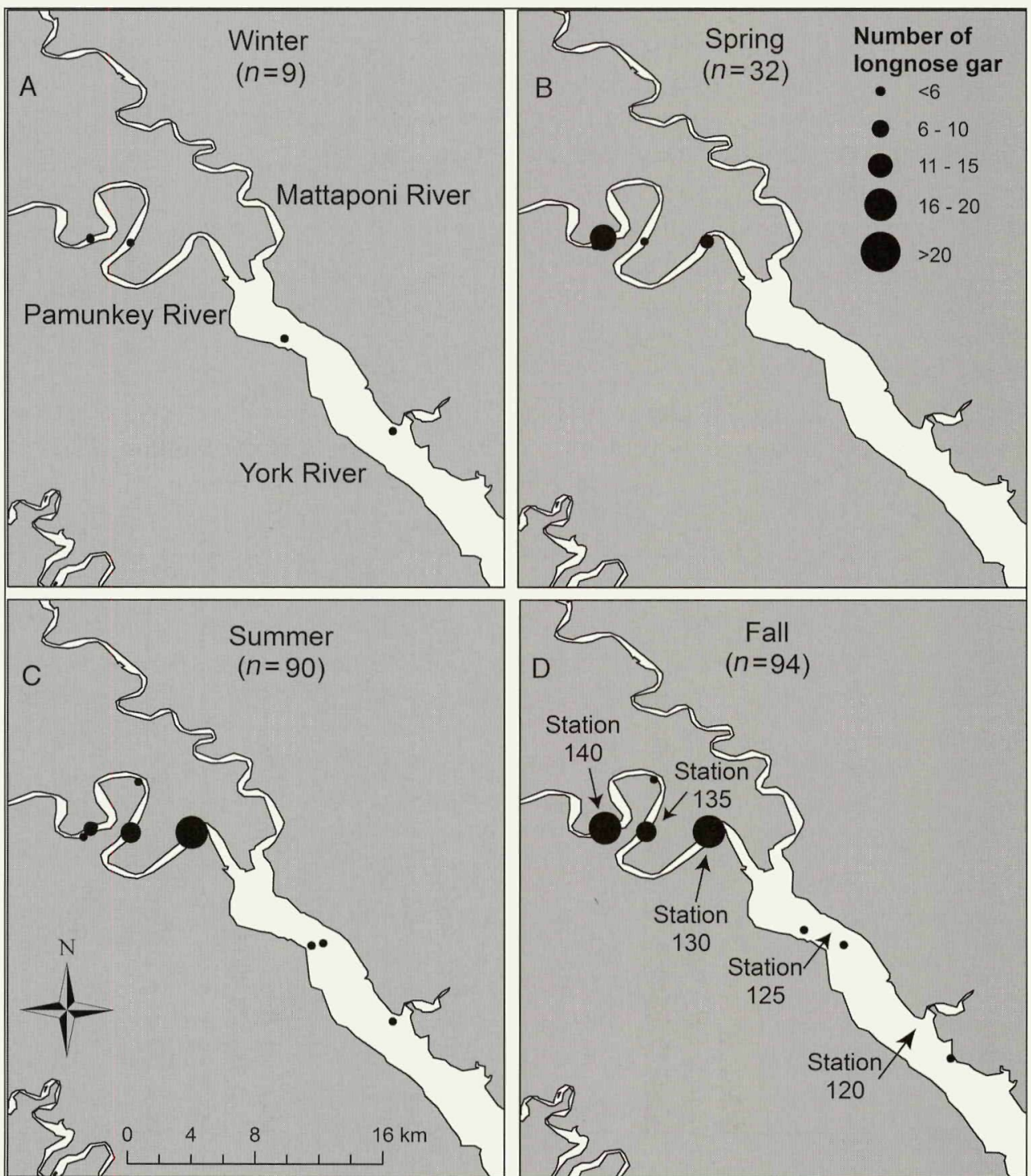

Figure 2. Location of VIMS juvenile finfish and blue crab trawl survey index stations and seasonal catch distributions and total number of Longnose Gar from 1989-2008: A) winter, B) spring, C) summer, and D) fall. 
Gar (48 km; Johnson and Noltie 1996). The longer distance traveled by fish in this study might be due to physical differences between the two study sites. Johnson and Noltie (1996) tagged fish in a small creek tributary of the Harry S. Truman Reservoir, while our study was done in a large riverine system. The long-distance movements were also greater than the furthest known movements of acoustically tagged Alligator Gar (Sakaris et al. 2003). Typically, larger fishes require greater space and move farther than smaller fishes (Jones 2005, Minns 1995). However, only one third $(n=5)$ of the tagged Alligator Gar in that study were relocated more than five times. Further research is needed to properly investigate if individual Longnose Gar have a greater range than Alligator Gar.

The VIMS Juvenile Finfish and Blue Crab Trawl Survey does not encompass the entire range of Longnose Gar in Virginia, but it does encompass a wide range of habitats based upon levels of salinity. Longnose Gar were never caught in water with a salinity value higher than 18 ppt even though they are commonly found in the Cape Fear River estuary at higher salinities (Schwartz 2003). An upriver spring spawning migration was evident in the trawl-survey catch distribution; after the spawning season, Longnose Gar appear to disperse downstream. Catches were most evenly distributed among all sites during the fall and winter.

The ability of Longnose Gar to withstand a range of salinity values (0-31 ppt; Jean 1946, Schwartz 2003) and its dependence on freshwater to spawn, forces a portion of the population to travel great distances each spring. Future work should explore whether Longnose Gar fit within Clark's contingency theory, which states that members of a migratory population have contingents that maintain their integrity by each "engaging in a distinct pattern of seasonal migrations not shared

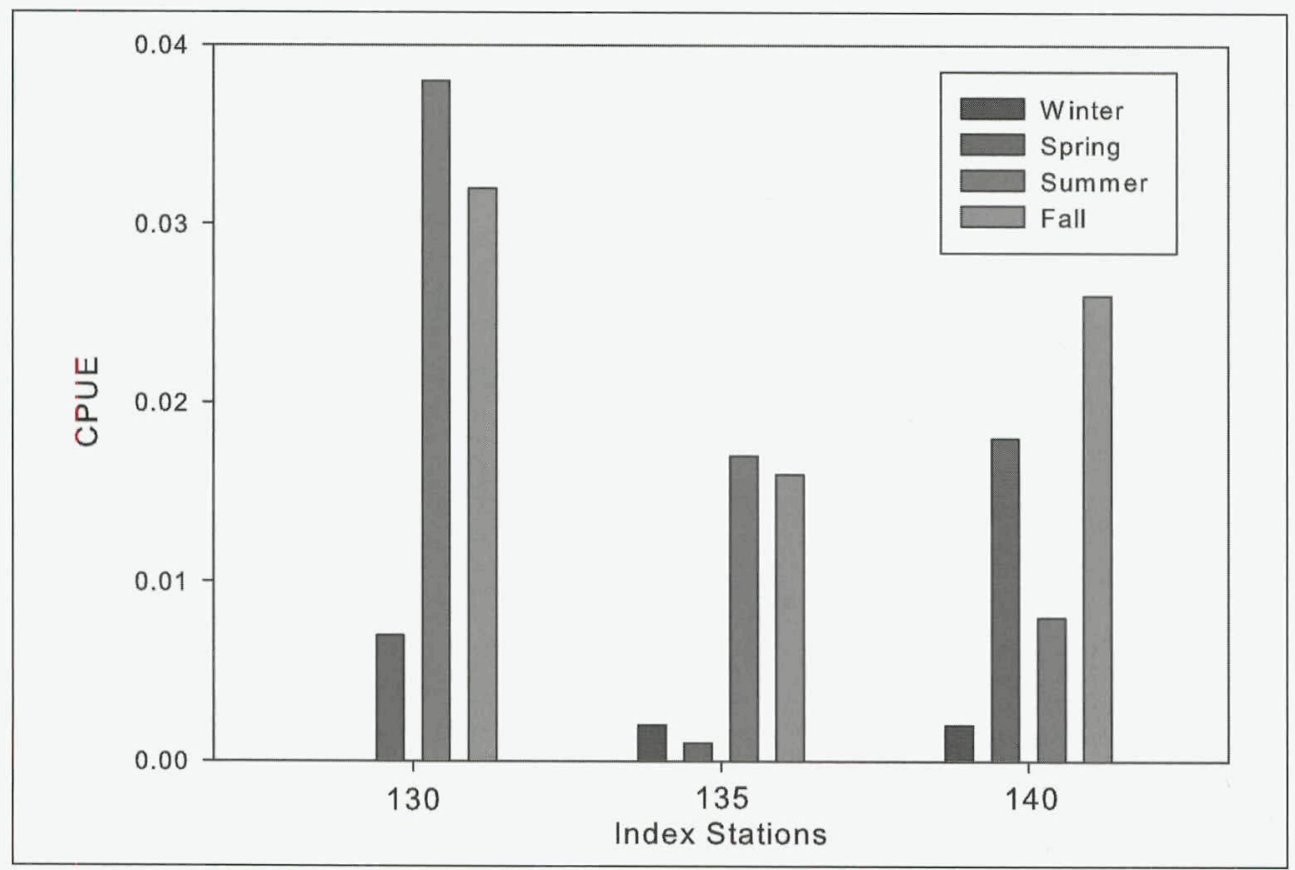

Figure 3. Seasonal catch per unit effort (CPUE) at three index stations in the Pamunkey River. 
by fish of other contingents" (Clark 1968:337). Studies in similar tidal riverine systems as the YRS have demonstrated contingents for Morone saxatilis Walbaum (Striped Bass; Secor 1999) and M. americana Gmelin (White Perch; Kraus and Secor 2004). White Perch occur in similar habitat and undergo similar spring spawning migrations as Longnose Gar (Kraus and Secor 2004), but it remains to be determined if they also have similar brackish and freshwater contingents.

\section{Spawning-site movements}

Two acoustically tagged Longnose Gar remained around the spawning grounds and were relocated by the listening station, providing some insight into possible spawning behavior. LNG21 and LNG22 were tagged during the spawning season and located by the listening station periodically for one month. The cessation of spawning, based on not having recorded them again at the listening station, appears to have occurred during the same week in late June for both individuals. This time frame for the end of spawning was also confirmed with a lack of egg collections and a decrease in GSI values (P.E. McGrath, unpubl. data). The duration for these individuals on the spawning grounds is consistent with previously reported spawning residency times of Longnose Gar (Johnson and Noltie 1996). Residency times on the spawning grounds in this previous study ranged from 15 to 94 days, with males staying on the spawning grounds longer than females (Johnson and Noltie 1996). Unfortunately, complete residency times from the current study are underestimates because it is unknown when each fish arrived at the spawning grounds.

Although the total duration was similar, the behavior on the spawning grounds was markedly different between the two tagged Longnose Gar. LNG21 was only located within the area of detection during low tide. Spawning at low tide may enable Longnose Gar to locate areas of vegetation that remain submerged at the lowest water levels, preventing the eggs from desiccating. Conversely, LNG22 did not display tidal periodicity, but rather swam evenly within the area of detection at all stages of the tide cycle. This fish was also located more often and remained within the area of detection for longer periods of time, although it is impossible to determine if courtship or spawning was occurring during this entire time or only around low tide.

The next step before proceeding with future lepisosteid tagging studies should be a controlled tank study to examine the effects of the surgical procedures and tag placement on Longnose Gar. Previous acoustic tagging studies on Spotted Gars (Snedden et al. 1999) and Alligator Gars (Sakaris et al. 2003) also did not complete a controlled tank study, and it is unknown if these stressors affect the behavior or mortality of the individual. Future studies may also want to experiment with the type of acoustic tag. The Mattaponi and Pamunkey rivers are muddy and brackish below RKM 75, which may have had a negative impact on our radio tags that were designed for low-conductivity rivers (Winter 1996). An attempt was made to locate Longnose Gar in brackish water with the dual radio/ ultrasonic transmitters, but only one of the four fish was relocated (LNG49), and this fish was never relocated in brackish water. 


\section{Conclusion}

This study represents the first attempt to acoustically tag Longnose Gar for the purpose of describing seasonal and short-term movements, and is the first to examine the movements and distribution of Longnose Gar inhabiting an estuarine river system. Long-distance movements and spawning site residency and behavior were recorded for a few individuals, but additional tagging studies are needed to confirm these results. This project provides the first description of spawning residence times for Longnose Gar in tidal rivers; however, many questions remain regarding their behavior at spawning locations in tidal systems versus those in non-tidal freshwater lakes and rivers. Additional studies are needed to determine spawning-site residency times, spawning-site fidelity during one year and between years, and possible intermittent use of spawning sites coinciding with tidal periodicity. Identification of the sex of the tagged individuals (e.g., see McGrath and Hilton 2012) will also enable future tagging studies to better examine the spawning behaviors of males and females. The present study is also the first description of Longnose Gar winter distributions, which were similar to areas utilized during fall and summer. Further research is warranted on the behavior and distribution of Longnose Gar to have a better understanding of the ecology of these apex predators.

\section{Acknowledgments}

We thank the VIMS Juvenile Striped Bass Seine Survey and VIMS Pushnet Survey for assisting with specimen collection for this study, as well as numerous volunteers for their field assistance. We thank J. Brubaker, R. Latour, T. Munroe, and 2 anonymous reviewers for comments on a draft of this manuscript. This project was conducted under IACUC \#20051006. Funding was provided by NSF grant DGE-084084 and the Department of Fisheries Science (VIMS). This is contribution number 3220 of the Virginia Institute of Marine Science, College of William and Mary.

\section{Literature Cited}

Clark, J. 1968. Seasonal movements of Striped Bass contingents of Long Island Sound and the New York Bight. Transactions of the American Fisheries Society 97:320-343.

Friedrichs, C.T. 2009. York River Physical Oceanography and Sediment Transport. Journal of Coastal Research 57:17-22.

Jean, Y. 1946. Two Northern Longnose Gar, Lepisosteus osseus oxyurus Rafinesque, caught in the estuary of the St. Lawrence, Quebec. Copeia 2:100.

Johnson, B.L., and D.B. Noltie. 1996. Migratory dynamics of stream-spawning Longnose Gar (Lepisosteus osseus). Ecology of Freshwater Fish 5:97-107.

Jones, K.M. 2005. Home range areas and activity centres in six species of Caribbean wrasses (Labridae). Journal of Fish Biology 66:150-166.

Kraus, R.T., and D.H. Secor. 2004. Dynamics of White Perch (Morone americana) population contingents in the Patuxant River estuary, Maryland, USA. Marine Ecology Progress Series 279:247-259.

Leggett, W.C. 1977. The ecology of fish migrations. Annual Review of Ecology and Systematics 8:285-308. 
McGrath, P.E., and E.J. Hilton. 2012. Sexual dimorphism in Longnose Gar (Lepisosteus osseus) from tidal rivers of Virginia. Journal of Fish Biology 80:335-345.

Minns, C.K. 1995. Allometry of home-range size in lake and river fishes. Canadian Journal of Fisheries and Aquatic Sciences 52:1499-1508.

Moore, K.A. 2009. Submerged aquatic vegetation of the York River. Journal of Coastal Research 57:50-58.

Murdy, E.O., R.S. Birdsong, and J.A. Musick. 1997. Fishes of Chesapeake Bay. Smithsonian Institution Press, Washington, DC. 324 pp.

Nichols, M., S. Kim, and C. Brouwer. 1991. Sediment characterization of the Chesapeake Bay and its tributaries, Virginian Province. National Estuarine Inventory Supplement. NOAA Strategic Assessment Branch. Silver Spring, MD. 88 pp.

Orth, R., D. Wilcox, L. Nagey, A. Owens, J. Whiting, and A. Kenne. 2005. 2004 distribution of submerged aquatic vegetation in Chesapeake Bay and coastal bays. Virginia Institute of Marine Science Special Scientific Report \#146. Gloucester Point, VA.

Perry, J.E., and R.B. Atkinson. 2009. York River Tidal Marshes. Journal of Coastal Research 57:40-49.

Reay, W.G., and K.A. Moore. 2009. Introduction to the Chesapeake Bay National Estuarine Research Reserve in Virginia. Journal of Coastal Research 57:1-9.

Sakaris, P.C., A.M. Ferarra, K.J., Kleiner, and E.R. Irwin. 2003. Movements and home ranges of Alligator Gar in the Mobile-Tensaw Delta, Alabama. Proceedings of the Annual Conference of Southeastern Associations of Fish and Wildlife Agencies 57:102-111.

Secor, D.H. 1999. Specifying divergent migrations in the concept of stock: The contingent hypothesis. Fisheries Research 43:13-34.

Schwartz, J. 2003. Longnose gar, Lepisosteus osseus (Family Lepisosteidae) in North Carolina, especially the Cape Fear River. Journal of The North Carolina Academy of Science 119:26-32.

Shields, E.C. 2008. Influences of habitat conditions on submerged aquatic vegetation development in the Chickahominy River and other Virginia tributaries of the Chesapeake Bay. M.Sc. Thesis. College of William and Mary, Williamsburg, VA. 141 pp.

Sisson, G., J. Shen, S. Kim, J. Boone, and A. Kuo. 1997. VIMS three-dimensional hydrodynamic-eutrophication model (HEM-3D): Application of the hydrodynamic model to the York River system. SRAMSOE Report No. 341. Virginia Institute of Marine Science. Gloucester Point, VA. 123 pp.

Snedden, G.A., W.E. Kelso, and D.A. Rutherford. 1999. Diel and seasonal patterns of Spotted Gar movement and habitat use in the Lower Atchafalaya River Basin, Louisiana. Transactions of the American Fisheries Society 128:144-154.

Tuckey, T.D., and M.C. Fabrizio. 2010. Estimating relative juvenile abundance of ecologically important finfish in the Virginia portion of Chesapeake Bay. Project \# F-104R-14. Annual Report to the Virginia Marine Resources Commission. Virginia Institute of Marine Science, Gloucester Point, VA. 84 pp.

Winter, J. 1996. Advances in underwater biotelemetry. Pp. 555-590, In B.R. Murphy and D.W. Willis (Eds.). Fisheries Techniques, Second Edition. American Fisheries Society, Bethesda, MD. 732 pp. 
Copyright of Southeastern Naturalist is the property of Humboldt Field Research Institute and its content may not be copied or emailed to multiple sites or posted to a listserv without the copyright holder's express written permission. However, users may print, download, or email articles for individual use. 